\title{
TERMELÉSI HÁLÓZATOK GYÁRAINAK ÖSSZESÍTETT TELJESÍTMÉNYMÉRÉSE TÖBBVÁLTOZÓS DÖNTÉSI MODELLEK ALKALMAZÁSÁVAL
}

\begin{abstract}
A teljesítmény mérése kulcsfontosságú minden üzleti folyamat irányításában, így azokban a teljesítményfejlesztő programokban is, melyeket számos nemzetközi termelési hálózat vezetett be az elmúlt évtizedekben. A szerzők munkája kiegészíti azt a viszonylag csekély számú kvantitatív kutatást, melyek a teljesítménymutatók szerepét vizsgálták a teljesítményfejlesztő programok kontextusában. Vizsgálatuk célja négy többváltozós döntési modellen alapuló teljesítményösszegzési és rangsorolási módszer összehasonlító elemzése és ezek alapján olyan módszerre javaslattétel, mely hatékonyan tudja támogatni a teljesítményfejlesztő programokat. A kutatás egy olyan multinacionális vállalat esettanulmányán alapul, ami több éves tapasztalattal rendelkezik a teljesítményfejlesztő program megvalósításában. Az elemzés eredményei felhívják a figyelmet a Borda módszeren alapuló rangsor hiányosságaira, leírják a TOPSIS-módszer és a hasznossági függvények alkalmazásának lehetséges előnyeit, és bemutatják, hogy miként lehet a gyárak és a hálózat egészének teljesítmény javulását nyomon követni e módszerekkel.
\end{abstract}

Kulcsszavak: teljesítménymenedzsment, többszempontú döntési modellek, teljesítményösszegzési módszerek, TOPSIS

A nemzetközi termelési hálózatok gyárai különleges versenyelönnyel rendelkeznek a piacon egyedül versenyző társaikkal szemben, melynek forrása a hálózat speciális üzleti folyamatai által kifejlesztett egyedi képességek (Colotla et al., 2003). Ilyen speciális folyamatok a termelési hálózat gyárait felölelö, koordinált képességfejlesztő programok vagy a teljesítmény összehasonlításának (benchmarking) folyamatai (Shi - Gregory, 1998). A koordinált képességfejlesztés, a legjobb termelési gyakorlat átültetése a hálózat összes gyárába legtöbbször egy, a hálózatra szabott termelési rendszer bevezetése által történik, mely ismert módszereken, mint például a lean vagy a Six-Sigma alapul (Netland - Aspelund, 2013; Shi - Gregory, 1998). Az utóbbi időben számos termelési hálózat indított üzleti teljesítményének javítása érdekében képességfejlesztésen alapuló teljesítményfejlesztő programot (Netland - Aspelund, 2014). E programok eredményességét a vállalati teljesítmény nyomon követésével lehet igazolni. A teljesítmény mérése minden vállalat müködésének elengedhetetlen része, ez biztosítja a keretet a „tervezés - célkitüzés - ellenőrzés” üzleti folyamathoz (de Waal, 2004). A teljesítménymérés ad visszajelzést arról, hogy a vállalat hol tart céljai elérésében és információt nyújt a döntésekhez (Kovács, 1999; Wimmer, 2014). Így a teljesítményfejlesztő programoknak is nélkülözhetetlen része a teljesítmény mérése, mely biztosítja a fejlődés nyomon követését, a legjobb gyakorlatok azonosítását és megosztását. A teljesítmény mérésével együtt jár a programban részt vevő vállalatok versengése is (Lai et al., 2016), mely rosszul megválasztott teljesítménymutatók esetén ronthatja a tudásmegosztást és így a teljesítményfejlesztő program eredményességét (He et al., 2014; Pfeffer - Sutton, 1999).

A termelési hálózatok teljesítményfejlesztő programjainak eredményességéről viszonylag kevés kvantitatív információ áll rendelkezésünkre, a kutatások nagyobb részt kvalitatív, felméréseken alapuló adatokra támaszkodnak, ami megállapításaikat gyengítheti (Netland - Aspelund, 2014). A teljesítmény mérése ezért nagyobb figyelmet érdemel e programok eredményességének értékelésében. A teljesítménymutatók témaköre a szakirodalom által jól feldolgozott terület. Számos kutatás vizsgálta, hogy a különböző üzleti folyamatok teljesítményének mérésére milyen mutatókat érdemes választani (Neely et al., 1995; Stephens, 2001; Wimmer, 2014) és hogyan lehet a vállalat egészére egy kiegyensúlyozott teljesítménymutatószám-rendszert kidolgozni. A teljesítménymutatók összegzésének számos többváltozós döntési modellen alapuló módszere ismert. A legegyszerübb a Borda-féle sorrend (de Borda, 1781), mely nem tesz különbséget az egyes teljesítménymutatók fontossága között és kizárólag sorrendjüket vizsgálja. A mutatók relatív fontosságának megállapítására gyakran alkalmazott módszer az Analytic Hierarchy Process (AHP) (Saaty, 1986, 1977), míg a mutatók értékét a TOPSIS (Techniqe for Order Preference by Similarity to Ideal Solution) (Hwang - Yoon, 1981) az ideális megoldáshoz való hasonlóság sorrend-preferencia módszerével, vagy hasznossági függvényekkel (Pomerol - Barba-Romero, 2000) vehetjük figyelembe. A TOPSIS-módszer egy összesített teljesítménymutatót eredményez, míg a hasznossági függvények esetében azt súlyozott átlagként számolhatjuk ki (Rangone, 1996).

A cikkben ismertetett kutatás célja négy különböző teljesítményösszegzési és rangsorolási módszer összehasonlító elemzése a termelési hálózatok teljesítményfejlesztő programjának kontextusában. A kutatás módszertana esettanulmány-alapú, mely az SABMiller plc, egy 
multinacionális italipari vállalat gyárainak adatain alapul. A gyárak több éven keresztül lean alapokon nyugvó képesség- és teljesítményfejlesztő programban vettek részt, melynek részét képezte egy teljesítménymutatókon alapuló ösztönző rendszer. Az ösztönző rendszer a vállalatok között kialakított verseny által kívánta elösegíteni a legjobb gyakorlatok azonosítását, átadását és bevezetését, végeredményben a tudásmegosztást. Az ösztönző rendszer a gyárak teljesítménymutatóinak Borda rangsorán alapult, melynek alkalmazhatóságával kapcsolatban számos kritika fogalmazódott meg, és ez a gyárak közötti együttmüködést is negatívan befolyásolta. A legfőbb kritika azzal kapcsolatban merült fel, hogy a Borda rangsor mennyire képes megjeleníteni a teljesítmény mértékében tapasztalható különbségeket és figyelembe venni a mutatók eltérő fontosságát. A vállalat ezért olyan teljesítményösszegzési és rangsorolási módszert keresett, amely hitelesebben jeleníti meg a vállalatok tényleges teljesítményét, azok egymáshoz való viszonyát. A kutatás e módszerek feltárását, elemzését és az elemzés eredményein alapuló teljesítményösszegzési módszer kiválasztását célozza meg.

A cikk először a termelési hálózatok teljesítményfejlesztő programjait, az ahhoz kapcsolódó teljesítménymutatókat, azok kiválasztásának gyakorlatát vizsgálja, majd kitér a teljesítménymutatók összegzésének módszereire. Bemutatja a többváltozós döntési modelleken alapuló Borda, AHP és TOPSIS-módszereket, illetve a hasznossági függvények alkalmazását. Az irodalmi áttekintés a témában fellelhető, termelővállalatokra vonatkozó teljesítményösszegző kutatásokat tekinti át. A módszertani rész bemutatja az adatok forrását és az összesített teljesítménymutatók létrehozásához alkalmazott kvalitatív módszereket. Az esettanulmány rész ismerteti a vizsgált termelési hálózatot, az általa múködtetett teljesítményfejlesztő programot, a vizsgált teljesítményösszegző módszerek közötti különbségeket és a különbségek mögött meghúzódó okokat az esettanulmány kontextusában. Megvizsgálja a módszerek gyakorlati alkalmazhatóságát és javaslatot tesz egy olyan teljesítményösszegzési módszerre, amely kiküszöböli az eddig alkalmazott eljárások hiányosságait és kielégíti a kutatási kérdésekben megfogalmazott elvárásokat. A cikk összefoglalóval zárul, megválaszolva kutatási kérdéseinket.

\section{Irodalmi áttekintés}

\section{A teljesítménymutatók szerepe a teljesítményfejlesztő programokban}

Az elmúlt évtizedekben a multinacionális vállalatcsoportok - kihasználva a globalizáció adta lehetőségeket - jelenlétüket a világ nagy részére kiterjesztették. Ez részben helyi vállalatok felvásárlásával, részben pedig új, zöldmezős beruházások által történt. A gazdasági környezet romlásával és a verseny erősödésével a vállalati teljesítmény csoportszintü javítása egyre fontosabbá vált (Netland Aspelund, 2014). A vállalatcsoporton belüli tudásmegosztásnak és a legjobb gyakorlat átültetésének, mint különleges versenyelönynek (Colotla et al., 2003; Shi - Gregory, 1998) a lehetőségét kihasználva számos termelési hálózat indított csoportszintü teljesítményfejlesztő programot. Ezek a programok egyrészt a vállalatok közötti vertikális és horizontális koordinációs tevékenységek elmélyítését, másrészt pedig a vállalaton belüli folyamatok javítását célozzák meg (Netland - Aspelund, 2014). A csoportszintü koordinációs tevékenységek közé tartoznak többek között a kapacitástervezés, az új termékfejlesztés és a teljesítmény összehasonlításának (benchmarking) folyamatai (Shi - Gregory, 1998). A vállalaton belüli folyamatok javítását azok szabványosításával, a legjobb gyakorlat kötelező bevezetésével, vagy önkéntes átültetésével, a helyi körülményekhez való alakításával érik el (Mefford - Bruun, 1998; Netland - Aspelund, 2014). Az, hogy a kötelező bevezetés vagy az önkéntes átültetés dominál-e, számos tényezőtől függ, beleértve a teljesítményfejlesztő program stratégiai megközelítését is. A vállalat felső vezetése fontos szerepet játszik a koordinációs tevékenységek meghatározásában, müködtetésében, melynek kitüntetett tényezői a közös célok, a közös jövőkép és a kölcsönös bizalom (Singh, 2013).

A multinacionális vállalatcsoportok teljesítményfejlesztő programjainak kutatásában a kvalitatív elemzések dominálnak, viszonylag kevés, ami a teljesítményjavulás mértékét kvantitatív módon vizsgálja (Netland - Aspelund, 2014). A kvantitatív kutatások közül hármat emelnénk ki, melyek rávilágíthatnak e programok fontosságára és a teljesítménymérésnek abban betöltött szerepére. Az első Ferdows és Thurnheer (2011) cikke, amely egy extrudált alumíniumtermékeket gyártó globális csoport teljesítményfejlesztő programját vizsgálta. A teljesítménymutatókat, melyek a munkabiztonságra, a folyamatképesség javítására, a rugalmasságra és a termelékenységre összpontosítottak, nem csak a program sikerének figyelemmel követésére használták, hanem a projekt irányítására és motivációra is. Fontosnak tartották, hogy a vállalati képességek és a hozzájuk kapcsolódó teljesítménymutatók egyidejüleg, több területen is javuljanak. A program során azt tapasztalták, hogy a teljesítménymutatók hatásosabbak, ha nem azok abszolút értékére, hanem változásukra, javulásukra helyezik a figyelmet. A program eredményeként a munkabalesetek száma évente megközelítőleg 14\%kal csökkent, míg a termelékenység évente megközelítőleg 4\%-kal nőtt. A minőség és a rugalmasság javulásának elemzéséhez sajnos nem állt rendelkezésükre elegendő információ.

A másik kutatás Swink és Jacobs (2012) munkája, mely 200 Six-Sigma képességfejlesztési módszert alkalmazó cég pénzügyi teljesítményének változását vizsgálta. A Six-Sigma módszer célja a folyamatok szórásának csökkentése segítségével a vállalat stratégiai céljainak megvalósítása (Schroeder et al., 2008). A módszer kiterjedten alkalmaz statisztikai módszereket, az adatokra támaszkodó problémamegoldást és feltételezi a termelési hálózat által működtetett központi struktúra meglétét, mely erőforrásokat biztosít a tudásmegosztáshoz és a fejlesztési projektekhez. Swink és Jacobs kutatása a jövedelmezőség, illetve annak komponensei, az értékesítésre vetített alapanyag és rezsiköltség, valamint az értékesítés árbevételének változásán, mint 
teljesítménymutatókon keresztül vizsgálta a Six-Sigma módszer eredményességét. Az adatok a Compustat adatbázisból származtak és a mutatók változását egy kontrollcsoporttal összehasonlítva elemezték öt év távlatában. A Six-Sigma módszert alkalmazó vállalatok jövedelmezősége a vizsgált időszakban szignifikánsan jobban változott, mint a kontrollcsoporté, elsősorban a költségek csökkentése miatt.

Végül Demeter és Losonci (2011) kutatása a lean termelési módszerek és az üzleti teljesítmény közötti kapcsolatot elemezte. A lean módszerek fellelhetök a legtöbb teljesítményfejlesztő programban, így bár kutatásuk nem kifejezetten egy termelési hálózat gyáraira irányult, vizsgálatuk módszertana és eredménye felhasználható a termelési hálózatok kontextusában is. Az üzleti teljesítmény változását négy kritériumon keresztül vizsgálták, melyek az értékesítés árbevétele, a piaci részesedés, az árbevétel-arányos megtérülés és a beruházásmegtérülés mértéke volt. Az operatív mutatókat, mint például a gyártás minősége, a szállítás megbízhatósága, a gyártási költség vagy a munkaerő termelékenysége, kérdőíves felmérés alapján mérték. Az üzleti teljesítmény mutatói nem adtak szignifikáns eltérést, de az operatív mutatók a gyártási költség kivételével minden mutatóban szignifikánsan, pozitívan eltértek a lean módszereket alkalmazó gyárak javára. Kutatásuk eredménye rávilágít arra, hogy a pénzügyi mutatók nem feltétlenül képesek megjeleníteni a lean módszer által biztosított előnyöket, arra inkább az operatív mutatók lehetnek alkalmasak.

A fenti kutatások jól mutatják, hogy teljesítménymutatók segítségével a teljesítményfejlesztési programok sikere nyomon követhető. A csekély számú kvantitatív kutatással kapcsolatban Netland és Aspelund (2014) felhívja a figyelmet arra, hogy több olyan munkára lenne szükség, ami teljesítménymutatókon és pénzügyi adatokon keresztül vizsgálja e programok eredményességét. Megállapítják azt is, hogy a kutatások nem adnak gyakorlati tanácsokat a legjobb gyakorlat önkéntes átültetésének elősegítésére, kimerülnek olyan felszínes javaslatokban, mint hogy ,növelni kell a vezetés elkötelezettségét" (Netland - Aspelund, 2014). Az önkéntes átültetés sikerét számos tényező befolyásolja, melyek közül az egyik meghatározó a menedzsmentre nehezedő nyomás (Ungan, 2005). Ezt a teljesítménymutatók összehasonlításával és nyomon követésével is befolyásolhatjuk, így a teljesítményfejlesztő programok szerves részét képező központi folyamatauditok és ösztönző programok (Netland - Aspelund, 2013) teljesítménymutatókkal való kiegészítése segíthet hatásosabbá tenni az önkéntes átültetést. Fontos azonban, hogy ez a nyomás ne legyen túlzott és a mutatók valósan tükrözzék a vállalatok tényleges teljesítményét, ellenkező esetben az a tudásmegosztást gátolhatja (Pfeffer - Sutton, 1999). Kutatásunk célja ezért annak vizsgálata, hogy miként lehet olyan összesített teljesítménymutató rendszert létrehozni, ami valósan tükrözi a vállalatok összesített teljesítményét, az a teljesítmény fejlesztésének elősegítésére megfelelő nyomást helyez a menedzsmentre, de nem vezet a vállalaton belüli túlzott versenyhez.

\section{A teljesítménymutatók és a teljesítménymutató rendszerek}

Ahhoz, hogy a teljesítményt javítani tudjuk, tudnunk kell azt mérni is. Deming gyakran idézett állítása, miszerint „amit nem tudunk mérni, azt nem is tudjuk kézben tartani” (Deming, 1994) jól rávilágít arra, hogy bármilyen üzleti folyamat irányításához számszerüsített adatokra van szükség. A vállalati teljesítmény olyan fogalom, amit gyakran említenek, de annál ritkábban határoznak meg (Neely et al., 1995). Neely és társai a vállalati teljesítmény két fö dimenzióját emelik ki: az eredményességet (effectiveness) és a hatékonyságot, gazdaságosságot (efficiency). Az elöbbi azt írja le, hogy egy vállalat milyen mértékben elégíti ki vevői elvárásait, illetve felel meg a vállalati céloknak, míg az utóbbi azt vizsgálja, hogy a rendelkezésére álló erőforrásokat milyen hatékonysággal használja fel. Definíciójuk szerint a teljesítménymutató egy olyan metrika, ami egy tevékenység eredményességét és hatékonyságát számszerüsíti. Tangen (2005) cikkében részletes gyakorlati tanácsokat ad az egyes teljesítménymutatók kiválasztására, meghatározására és bevezetésére. Kiemel három kerülendő hibát: 1) a mutató, illetve a számítási mód indirekt módon sem szabad, hogy negatív magatartást váltson ki, 2) a mutató ne mérjen olyan dolgot, amelyre a vizsgált személy vagy szervezet nincs hatással és 3) a számítási mód ne tartalmazzon félrevezető súlyozást. Akyuz és Erkan (2010) a termelési hálózatok teljesítménymérésének irodalmát áttekintő cikkében a mutatókkal kapcsolatban Gunasekaran és Kobu (2007) kritériumait emeli ki, miszerint a helyes teljesítménymutatók: a) rávilágítanak a sikerre, b) megmutatják, hogy a vevők elvárásai teljesültek-e, c) segítenek jobban megérteni a folyamatokat, d) segítenek azonosítani a szűk keresztmetszeteket, veszteségeket, problémákat és fejlődési lehetőségeket, e) elősegítik a tényeken alapuló döntéshozatalt, f) elösegítik a fejlődést és annak nyomon követését, valamint g) elősegítik a nyílt és átlátható kommunikációt. A kutatások eredményeit vizsgálva megállapítják, hogy a teljesítménymutató rendszerek fö problémái a teljesség hiánya, az inkonzisztencia, a pénzügyi és működési teljesítménymutatók aránytalansága, valamint a vállalati stratégia leképezésének hiánya. Az operatív folyamatokhoz kapcsolható teljesítménymutatók szerepe az utóbbi időben ugyan növekedett, de továbbra is problematikus, hogy a cégek azt mérik, ami relatíve könynyen mérhető és a fókuszpontok nem feltétlenül egyeznek a vállalat stratégiájával (Zoltayné et al., 2007). Akyuz és Erkan (2010) egy modern teljesítménymutató rendszerrel szemben a következő főbb elvárásokat a fogalmazza meg:

- a rendszer a vállalat stratégiáján és céljain alapuljon, tükrözze a vállalati teljesítmény lényegét, legyen koherens és transzparens,

- a pénzügyi és nem-pénzügyi, valamint a stratégiai, taktikai és müködési mutatókat arányosan tartalmazza,

- a hasonló vállalatok mutatói összehasonlíthatók legyenek,

- a mutatók célja, adatainak forrása, számításuk módja legyen világos, azok legyenek megbízhatóak és érvényesek, 
- a rendszer tegye lehetővé célok kitűzését és az adatok összegzését - szétbontását, valamint rangsorolását és súlyozását,

- a mutatók átfedésektől mentesek legyenek,

- a rendszer legyen képes bonyolult állandó költségstruktúrák kezelésére,

- a mutatók legyenek egyszerüek, inkább hányadosok formájában, mint abszolút számokban kifejezettek,

- a nem-pénzügyi mutatók élvezzenek elsőbbséget az aggregált pénzügyi mutatókkal szemben, hogy azok alapján a szervezet cselekedni tudjon,

- a mutatók segítsék elő a proaktív hozzáállást, a gyors visszacsatolást és a folyamatos fejlödést,

- a mutatók legyenek felülvizsgálhatók és támogassák a szervezeti tanulást.

Wimmer (2004) cikkében a teljesítménymutatók rendszerével kapcsolatban egy olyan keretrendszert állít fel, mely segít vizsgálni, hogy az mennyiben támogatja az értékteremtő folyamatokat. Keretrendszere három fö elemből áll. Az orientáció leírja a teljesítménymérés fó célját és szerepét, ami lehet például ellenőrzés, beszámoltatás, a visszacsatolások biztosítása, a döntések támogatása vagy a tervezés elősegítése. A kiegyensúlyozottság a teljesítménymutató rendszer összhangját értékeli: mennyire tartalmazza az a versenytényezőket, alkalmazza-e a folyamatszemléletet és a felhasznált információ mennyire épül belső-külső, illetve szubjektív-objektív elemekre. A keretrendszer harmadik eleme, a konzisztencia pedig azt vizsgálja, hogy az egyes teljesítménymutatók fontossága és használata mennyire egyezik a vállalat stratégiájával.

A SCOR-rendszer (Supply Chain Operations Reference Model) (Stephens, 2001; Supply Chain Council, 2012), melyet kifejezetten a termelési hálózatok teljesítménymutatói számára dolgoztak ki, lehet példa egy olyan rendszerre, ami megfelel a fent megfogalmazott számos elvárásnak. Felöleli a termelési hálózat teljes területét a beszállítók által biztosított termékek beérkezésétől a késztermék kiszállításának logisztikájáig, beleértve az alapanyagok feldolgozását, a gyártást és a termelési hálózat folyamatainak támogatását, valamint az ehhez kapcsolódó tervezést. A rendszer nagyszámú teljesítménymutatót definiál, mely elősegíti a rendszert alkalmazó vállalatok teljesítményének objektív módon történő összehasonlítását. Segítségével megfelelő orientációjú, kiegyensúlyozott és konzisztens teljesítménymutató rendszer építhető fel.

\section{A teljesítménymutatók összegzésének módszerei}

A teljesítménymutatók összegzésének számos módszere alapul a többváltozós döntési modelleken (Ho et al., 2010). E módszerek alkalmazásakor a vállalatokat döntési alternatívákként, a teljesítménymutatókat pedig döntési változókként kezeljük, utóbbiak az összesített teljesítmény egy-egy aspektusát írják le. Az összegzés célja lehet a vállalatok teljesítmény-rangsorának megállapítása vagy az összesített teljesítmény valamilyen skálán történő ábrázolása, a teljesítménykülönbségek mértékének összehasonlítása céljából. A többváltozós döntési modelleknél feltételezzük a döntéshozó preferenciáinak additivitását (Fishburn, 1967), vagyis azt, hogy az összesített preferencia-sorrendet az egyes döntési változók preferencia-sorrendjének összegeként képezhetjük.

\section{A teljesítmény rangsorolása Borda módszerrel}

A teljesítménymutatók összesített rangsorát legegyszerübben a Borda módszerrel (de Borda, 1781) határozhatjuk meg. Minden egyes teljesítménymutatóra, mint döntési változóra megállapítjuk a vállalatok sorrendjét és ezekhez sorrendpontszámokat rendelünk úgy, hogy a legjobb teljesítményü vállalatnak adjuk a legalacsonyabb pontszámot, az ezt követőnek eggyel nagyobbat és így tovább. Holtverseny esetén az azonos teljesítményt nyújtó vállalatok között a pontokat szét kell osztani. Az összesített sorrendet az egyes sorrendekhez rendelt pontszámok összegeként határozzuk meg, ahol a legnagyobb összesített teljesítményt a legalacsonyabb összpontszám, míg a legalacsonyabb teljesítményt a legnagyobb összpontszám jelenti. A módszer teljes rangsort állít fel a vállalatok között, egyszerüen megvalósítható, de hiányossága, hogy nem veszi figyelembe az egyes teljesítménymutatók közötti esetleges fontossági és értékbeli különbségeket, ami alááshatja a végeredmény hitelességét.

\section{A teljesítménymutatók fontosságának megállapítása AHP-módszerrel}

A döntési változók eltérő fontosságának figyelembe vételére dolgozta ki Saaty az 1970-es évek végén az Analytic Hierarchy Process (AHP) módszerét (Saaty, 1986, 1977). A teljesítménymutatók relatív fontosságának megállapításához azokat egy 1-9-ig terjedő Likert-skálán páronként összehasonlítjuk, ahol 1 azt jelenti, hogy a két teljesítménymutató fontossága megegyezik, 3 azt, hogy az első valamivel fontosabb, mint a második, 5 fontosabbat, 7 sokkal fontosabbat, míg a 9 extrém módon fontosabbat jelent. Amennyiben a fontosság sorrendje ellentétes, úgy $1 / 3,1 / 5,1 / 7$ és $1 / 9$ értékeket adunk és használhatjuk a köztes 2, 4, 6, 8 értékeket is az értékelés finomítására. Az összehasonlítások eredményét egy mátrixban ábrázoljuk és a teljesítménymutatók normalizált súlyát a mátrix domináns sajátvektorából számítjuk ki. Arra, hogy hány és milyen szakértőnek kell részt venni a páros összehasonlításokban nincs általános szabály, de az összehasonlítások konzisztenciáját ellenőriznünk kell, hogy kiszürjük az irracionális vagy véletlenszerü értékeléseket. Erre szolgál a konzisztencia index (Kwiesielewicz - van Uden, 2004). Az összesített mutató kiszámításához a módszer által meghatározott súlyokkal összegezzük a teljesítménymutatók valamilyen módon transzformált értékeit (Rangone, 1996). A módszer előnye, hogy nagyszámú mutató esetén is meg tudjuk határozni azok fontossági súlyát, azok hierarchiába rendezésével és páros összehasonlításával. Az összehasonlítások inkonzisztenciája különösen nagyszámú mutató esetén valós probléma, melynek megoldásában a módszer általánosabb formája, az Analytic Network Process (ANP) (Saaty, 2004) vagy annak fuzzy logikán (Kása - Réthi, 2017) alapuló kiterjesztése segíthet. Az előbbi az egyes mutatók egymásra gyakorolt hatását, míg 
az utóbbi a páros összehasonlításokhoz kapcsolódó döntések bizonytalanságát és pontatlan megfogalmazását segít figyelembe venni.

\section{A TOPSIS-módszer: a teljesítmény összegzése a legjobb és legrosszabb teljesítményhez mért távolságok által}

A TOPSIS-módszer az összesített teljesítményt a teljesítménymutatók többdimenziós terében értelmezett, az egyes alternatíváknak (gyáraknak) a legjobb (ideal), illetve a legrosszabb (anti-ideal) értékektől mért távolságaként méri. A módszer alkalmazásához a teljesítménymutatókat normalizálni kell, méghozzá olyan módon, hogy egy adott döntési alternatívára és teljesítménymutatóra vonatkozó értéket elosztjuk az adott teljesítménymutatóhoz tartozó összes alternatíva értékének összegével. Az így normalizált mutatókra minden egyes alternatíva esetében kiszámoljuk a döntési változók terében a legjobb és a legrosszabb értékektől mért euklideszi távolságot, amit súlyozhatunk az AHP-módszer segítségével meghatározott súlyokkal. Az egyes alternatívákhoz tartozó összesített teljesítményt úgy kapjuk, hogy a legrosszabb ponttól mért távolságot elosztjuk az ugyanezen alternatívához tartozó, a legjobb és legrosszabb ponttól mért távolság összegével. A végeredmény így azt adja meg, hogy az adott gyár összesített teljesítménye mennyire közelíti meg a többdimenziós térben a legjobb teljesítményt. Ezt úgy is értelmezhetjük, mint egy teljesítményhatékonyságot, ahol 0 a legrosszabb teljesítményt jelenti, míg 1 a legjobbat. A módszer a mutatók többdimenziós térben történő értelmezése miatt kifejező, a súlyozás alkalmazásával az egyes mutatók eltérő fontossága figyelembe vehető és eredménye könnyen értelmezhető. Hátránya lehet, hogy feltételezi az egyes mutatók legrosszabb és legjobb értékek közötti monoton, lineáris változását.

\section{Az összesített teljesítmény skálán történő ábrázolása hasznossági függvényekkel}

A hasznossági függvények a döntéshozó érzelmi preferenciáit fejezik ki és segítségükkel számszerüsíteni lehet, hogy a teljesítménymutató értékei közötti különbségek milyen mértékben változtatják meg ezt a preferenciát (Pomerol - Barba-Romero, 2000), mely nem feltétlenül változik lineárisan a teljesítménymutató változásával. A hasznossági függvény meghatározására számos módszer létezik (Fishburn, 1967). Érdemes megemlíteni a MACBETH-módszert (Measuring Attractiveness by a Categorical Based Evaluation TecHnique), mely az AHP-módszerhez hasonlóan páros összehasonlítások segítségével állapítja meg a mutatók kiválasztott értékeihez tartozó hasznossági függvény értékeket (Bana e Costa - Vansnick, 1994). Pennings és Smidts (2003) cikkében nem zárja ki, hogy a hasznossági függvény alakja hatással van a szervezeti döntésekre, így annak helyes megválasztásával azt befolyásolni lehet. Egy jól megválasztott hasznossági függvénnyel így le tudjuk írni a vállalat stratégiáját tükröző preferenciát, azaz, hogy meghatározott teljesítménytartományokban a teljesítmény változása milyen mértékben változtatja megelégedettségünket. A hasznossági függ- vények alkalmazásának előnye, hogy segítségével figyelembe vehetjük a mutatók értékei és a preferenciák közötti nem-lineáris kapcsolatot, meghatározásuk azonban magában hordozhatja a szubjektivitás problémáját.

\section{Az összesített teljesítményt vizsgáló kutatások}

A vállalatok összesített teljesítményét vizsgáló kutatások közül kettőt emelnénk ki, melyek az általunk is vizsgált összegzési módszereket alkalmazzák. Chan (2003) a termelés egy tágabban értelmezett területének, az ellátási láncoknak a teljesítménymutató rendszereit vizsgálta. A kutatás kvantitatív és kvalitatív mutatókat vizsgált, melyeket az AHP-módszer segítségével meghatározott súlyok alapján összegzett. A kvantitatív mutatók közé a költségek és a rendelkezésre álló erőforrások (munkaerő, berendezés kapacitások) kihasználtsága, míg a nagyszámú kvalitatív mutatókhoz a minőség és olyan fogalmak, mint a bizalom és innovációs képesség tartoztak. A kutatás nem közöl számszerü eredményeket az összesített mutatóra, de bemutatja, hogy a módszer használható egy kiegyensúlyozott mutatószámrendszer létrehozására. A második cikk Kocaoğlu, Gülsün és Tanyaş (2013) munkája, ami a SCOR-teljesítménymutatókat felhasználva, az AHP-módszer segítségével megállapított fontossági súlyokat figyelembe véve, a TOPSIS-módszer alkalmazásával számít összesített teljesítménymutatót. Módszerüket felhasználva nagyszámú, heterogén mutatóból tudtak öszszesített mutatót képezni, melyet több időszakra kiszámolva ki tudták választani a legjobb teljesítményü időszakot és kiszámolni az ahhoz tartozó teljesítményt. Kutatásunk - hasonlóan ehhez a két munkához - egy kiegyensúlyozott teljesítménymutató rendszer összesített mutatóját és annak időbeli alakulását kívánja vizsgálni.

\section{A kutatás bemutatása}

A kutatás a termelési hálózatokhoz tartozó gyárak összesített operatív teljesítménymutatóit, mint a teljesítményfejlesztő programok támogató eszközét vizsgálja. A kutatás során három kérdésre keressük a választ:

- Q1: melyik összegző és rangsoroló módszer jeleníti meg valósan a gyárak összesített teljesítményét?

- Q2: melyik módszer támogathatja legjobban a teljesítményfejlesztő programokat?

- Q3: melyik módszer alkalmas a teljesítmény időbeli nyomon követésére?

A kutatás négy módszert hasonlít össze: a Borda rangsort - az esettanulmány vállalatának teljesítményösztönző rendszere ezen alapult, az AHP-súlyozott Borda rangsort, az AHP-súlyozott TOPSIS-módszert, valamint egy AHP-súlyozott, hasznossági függvényen alapuló módszert. A kutatási kérdéseket a négy módszer eredményeinek elemzése által, az esettanulmányon keresztül kívánjuk megválaszolni.

\section{A kutatás módszertana}

A kutatás két módszertani megközelítést ötvöz: az egyik a kvantitatív eljárás, a többváltozós döntési módszerek 
alkalmazása, a másik pedig az esettanulmány-alapú módszer. Az esettanulmány-alapú módszert széleskörűen alkalmazzák komplex vezetéstudományi problémák elemzésére (Eisenhardt, 1989; Yin, 2003). Ebben az esetben ez a kvantitatív elemzés eredményét segít értelmezni az esettanulmány kontextusában, a vizsgált vállalattól származó, a teljesítménnyel kapcsolatos információk által.

Az esettanulmány adatai az SABMiller plc globális termelési teljesítmény adatbázisából származnak. A vállalat globális teljesítménymenedzsment folyamatának keretében a gyárak havonta szolgáltattak részletes termelési és teljesítményadatokat. Ebből 14 teljesítménymutatót vizsgáltuk, 4 kategóriában három év időszakában. A mutatók a minőséget, az energiafelhasználást, a veszteségeket és a csomagolás hatékonyságát (OEE Overall Equipment Effectiveness - teljes berendezés hatékonyság) (Muchiri - Pintelon, 2008) mérik (1.táblázat). A minőséghez kapcsolódó mutatók két csoportra oszthatók: a specifikációnak való megfelelés százalékosan méri, hogy a vizsgált minták milyen hányada felel meg a vállalat által meghatározott belső specifikációknak, míg az értéktípusú mutatók egy skálán mérik a fogyasztó számára fontos fizikai vagy kémiai paramétereket. Ez utóbbinál általában az alacsonyabb értékek jelentenek jobb minőséget. A víz- és energiafelhasználás az egységnyi termék előállításához felhasznált mennyiséget méri. A veszteség jellegű mutatók azt mérik, hogy egységnyi termék előállításakor a vizsgált alapanyag-komponensnek mekkora a vesztesége az elméletileg szükséges értékhez viszonyítva. Végül a csomagolási hatékonyság mutatói azt mérik, hogy az összes tervezett és kifizetett munkaóra alatt termelt mennyiség hogyan viszonyul az ugyanezen időtartam alatt elméletileg előállítható mennyiséghez. Ez a hatékonyság méri, hogy mennyi időveszteség merül fel a berendezések meghibásodása, az egyes termékek közötti átállás és egyéb, az üzem hatáskörébe tartozó okok miatt.

1. táblázat

Az esettanulmány teljesítménymutatói

\begin{tabular}{|c|c|c|}
\hline $\begin{array}{l}\text { teljesítmény- } \\
\text { kategória }\end{array}$ & kód & magyarázat \\
\hline \multirow{2}{*}{ minőség } & \multirow{2}{*}{$\begin{array}{l}\text { QUALITY } 1, \ldots \\
\text { QUAITY } 7\end{array}$} & $\begin{array}{l}\text { specifikációknak } \\
\text { való megfelelés }\end{array}$ \\
\hline & & $\begin{array}{l}\text { minőségmutató- } \\
\text { érték }\end{array}$ \\
\hline \multirow{2}{*}{$\begin{array}{l}\text { víz- és energiafel- } \\
\text { használás }\end{array}$} & \multirow{2}{*}{$\begin{array}{l}\text { ENERGY } 1, \ldots \\
\text { ENERGY } 3\end{array}$} & $\begin{array}{c}\text { fajlagos } \\
\text { energiafelhasználás }\end{array}$ \\
\hline & & $\begin{array}{c}\text { fajlagos } \\
\text { vízfelhasználás }\end{array}$ \\
\hline veszteségek & LOSS 1, LOSS 2 & $\begin{array}{l}\text { anyagveszteség } \\
\text { hányadosok }\end{array}$ \\
\hline \multirow{2}{*}{$\begin{array}{l}\text { csomagolási } \\
\text { hatékonyság }\end{array}$} & \multirow{2}{*}{ OEE 1, OEE 2} & $\begin{array}{l}\text { munkaerő- } \\
\text { hatékonyság }\end{array}$ \\
\hline & & $\begin{array}{c}\text { berendezés } \\
\text { meghibásodása }\end{array}$ \\
\hline
\end{tabular}

A mutatók a müködés legfontosabb területeit vizsgálják, lefedik a vállalat stratégiáját és hányadosok formájában kifejezettek. Nem vizsgáltuk részletesen, hogy a teljesítménymutató rendszer mennyiben felel meg a Wimmer (2004) által felállított keretrendszernek. A rendszer egy helyen tartalmaz átfedést: a két csomagolási hatékonyságmutató közül az egyik a másik részhalmaza. Ezt az átfedést érdemes a jövőben megszüntetni és olyan mutatókra bontani, melyek a csomagolás hatékonyságának jól elkülöníthető dimenzióit mérik. A vállalat - a későbbiekben ismertetett - az AHP-módszer segítségével meghatározott fontossági súlyokkal kívánta elérni a teljesítménymutatók stratégiának való megfelelést, azok konzisztenciáját.

A kvantitatív elemzés során az összesített teljesítményrangsort, illetve összesített teljesítménymutatót négy módszerrel számoltuk. A Borda rangsorhoz a gyárakat a 14 teljesítménymutató alapján sorba rendeztük, megegyező teljesítmény esetén a sorrendpontszámok átlagát vettük, és az összesített sorrendet a sorrendpontszámok összege alapján állapítottuk meg. A teljesítménymutatók fontossági súlyainak AHP-módszer szerinti megállapításához a mutatókat a teljesítménykategóriák hierarchiájába rendeztük, majd ezeket a kategóriákat és az azokba tartozó mutatókat a vállalat termelési szakemberei segítségével páronként öszszehasonlítottuk. A normalizált súlyokat a páros öszszehasonlítások mátrixának sajátvektora segítségével számítottuk ki. Az AHP-súlyozott Borda összesített teljesítménysorrendet a sorrendpontszámok és az AHP-súlyok szorzatösszege alapján állapítottuk meg. Az AHPsúlyozott TOPSIS összesített teljesítménypontszámot és teljesítménysorrendet az $\mathrm{R}$ programhoz készült 'topsis' csomaggal (Yazdi, 2013) számoltuk ki. A teljesítményadatokat az irodalmi áttekintésben leírt módon normalizáltuk, a súlyokhoz pedig az előbb ismertetett AHP-eljárás eredményeit vettük figyelembe. A legjobb, illetve legrosszabb teljesítményértékeknek a hároméves időtartam legjobb és legrosszabb eredményeit vettük, hogy a teljesítmény időbeli változását vizsgálni tudjuk. Végül az AHP-súlyozott hasznossági függvényen alapuló összesített teljesítménypontszámhoz és teljesítménysorrendhez egy olyan hasznossági függvényt definiáltunk, ami egy bizonyos teljesítmény-küszöbérték alatt 0 teljesítménypontot képez, majd innen a kiváló teljesítmény eléréséig lineáris skálát alkalmaz, egy küszöb teljesítménypontszám kezdettel. A kiváló és a maximális teljesítmény között a függvény egy, az elözőnél kisebb meredekségü lineáris skálát alkalmaz. A teljesítménypontszám maximumát vagy az elméletileg elérhető, vagy egy empirikusan megválasztott teljesítményértéknél éri el. A hasznossági függvény alakját az 1. ábra szemlélteti. A függvényt azért definiáltuk ilyen módon, hogy a gyárakat a teljesítményösztönző rendszer által egyrészt egy minimális küszöbteljesítmény elérésére sarkalljuk, másrészt a kiválónak tekinthető teljesítmény elérése után arra. hogy erőforrásaikat ne e mutató további javítására, hanem más teljesítménymutatókra összpontosítsák. 
1. ábra

A hasznossági függvény a teljesítménymutatók skálázásához

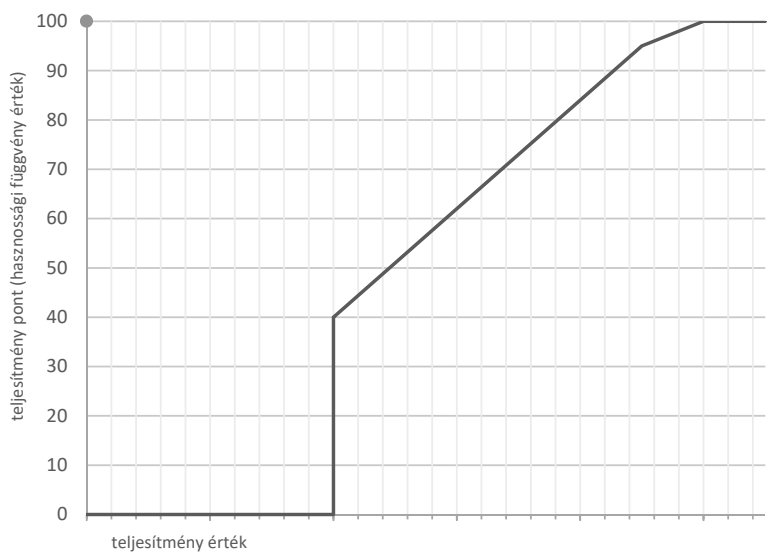

Forrás: saját szerkesztés

A négy módszer által kapott összesített teljesítményrangsorokat és értékeket összehasonlítottuk, és elemeztük az esetleges rangsorváltásokat. A különbségek okainak feltárásához egyrészt a részletes teljesítményadatokat használtuk, másrészt az esettanulmány által biztosított információkat, különös tekintettel a vizsgált gyárak teljesítményfejlesztő stratégiájára.

\section{A kutatás eredményei}

Az esettanulmány tárgya az SABMiller plc, egy rendkívül sikeres, globális italipari vállalat volt, mely 1999 és 2015 között 913,3\% -os TSR-eredményt (Total Shareholder Return: a részvény árfolyam emelkedésének és a kifizetett osztalékoknak az összege a kezdeti részvényértékhez viszonyítva) ért el (London Stock Exchange, 2015). A vállalat több mint 80 gyárat müködtetett a világ öt kontinensén, melyek egy közös, lean alapokon nyugvó termelési rendszer keretében fejlesztették képességeiket. A termelési rendszer részét képezte a teljesítménymutatók definíciója, azok eredményének a vállalat központi adatbázisában történő rendszeres rögzítése és auditálása. A gyárak termékportfóliója és az általuk alkalmazott technológia nagyon hasonló, ezért a teljesítménymutatók jól összehasonlíthatók, értékük különbsége nagyrészt olyan okokra vezethetö vissza, amire a gyárak hatással lehetnek. Azért, hogy a vállalat teljesítményét folyamatosan javítsa, globális teljesítmény-összehasonlítást és versenyt vezetett be, mely az általunk is vizsgált 14 teljesítménymutatón alapult. A vállalat sikerében teljesítményfejlesztő programja is szerepet játszott, ezért lehet hasznos az esettanulmány-alapú megközelítésen keresztül vizsgálni a teljesítménymutatók összegzésének problémáját.

Az esettanulmány 73 gyár teljesítménymutatóját vizsgálja a 2014 és 2016 közötti hároméves időszakban. A legtöbb mutató eloszlása nem felel meg a normális eloszlással szemben támasztott követelményeknek, ferdeségük a kiváló teljesítmény irányába mutat. A teljesítménymutatók főbb statisztikai mutatóit a 2.táblázat tartalmazza - a később részletezett - fontosságukat jelölő AHP-súlyokkal együtt. A mutatók értékei a TOPSIS-módszer által elvárt módon normalizáltak. A táblázatban az irány azt jelzi, hogy a jobb teljesítmény a mutatók kisebb (-) vagy nagyobb (+) értékéhez tartozik.

\section{A TOPSIS-módszer elvárásai szerint normalizált teljesítménymutatók összesített statisztikája és fontosságuk AHP-súlya}

\begin{tabular}{ccccccc}
\hline mutató & irány & átlag & szórás & ferdeség & csúcsosság & AHP-súly \\
\hline LOSS 1 & - & 0,0133 & 0,0037 & 0,9330 & 1,7887 & $2,00 \%$ \\
LOSS 2 & - & 0,0128 & 0,0087 & 2,9245 & 12,2668 & $8,90 \%$ \\
OEE 1 & + & 0,0134 & 0,0020 & $-0,2539$ & 0,0729 & $4,70 \%$ \\
OEE 2 & + & 0,0134 & 0,0010 & $-0,7753$ & 0,3213 & $2,70 \%$ \\
QUALITY 1 & + & 0,0134 & 0,0014 & $-3,1839$ & 12,2493 & $16,00 \%$ \\
QUALITY 2 & + & 0,0134 & 0,0027 & $-0,3436$ & 0,3544 & $3,70 \%$ \\
QUALITY 3 & + & 0,0135 & 0,0024 & $-2,1695$ & 5,8496 & $3,70 \%$ \\
\hline QUALITY 4 & + & 0,0134 & 0,0012 & $-1,7351$ & 4,6278 & $6,80 \%$ \\
QUALITY 5 & + & 0,0134 & 0,0014 & $-1,9834$ & 6,9415 & $6,80 \%$ \\
QUALITY 6 & - & 0,0123 & 0,0182 & 2,6041 & 6,3261 & $13,60 \%$ \\
\hline QUALITY 7 & - & 0,0130 & 0,0075 & 1,7162 & 6,8767 & $12,70 \%$ \\
ENERGY 1 & - & 0,0131 & 0,0034 & 2,0252 & 6,3842 & $6,40 \%$ \\
\hline ENERGY 2 & - & 0,0132 & 0,0042 & 1,0104 & 6,5141 & $8,00 \%$ \\
ENERGY 3 & - & 0,0132 & 0,0042 & 0,9826 & 1,2983 & $4,70 \%$ \\
\hline
\end{tabular}




\section{A Borda rangsor eredményei}

Az SABMiller plc globális teljesítmény-összehasonlítása és versenye az összesített Borda sorrenden alapult. Az módszer nem alkalmaz súlyozást, ezért az összesítésben a minőségmutatók nagy számuk miatt felülreprezentáltak. Az eredményeknek a kiváló teljesítmény irányába történő ferdesége azt eredményezi, hogy a kiváló teljesítményü gyárak között a verseny szorosabb, így kis teljesítményváltozás is nagy rangsorváltozást eredményezhet. A kiváló teljesítményű gyárak számára ezért előnyös lehetett erőforrásaikat a gyengébb mutatók fejlesztése helyett kiváló mutatóik további javítására összpontosítani, mivel az nagyobb hatással lehetett a végső sorrendre. A teljesítményverseny szabályai így nem feltétlenül vezettek a vállalat stratégiája szempontjából racionális döntésekhez, az a csökkenő hozadékú mutatók további javításán keresztül az erőforrások elpazarlását eredményezhette. A 3.táblázat első adatsora mutatja a 73 vállalat közül kiválasztott 7 gyár összesített Borda rangsorát. A gyárakat két régióból választottuk, amit a gyárak kódjában lévő betủ jelöl. Két gyár tartozik a leggyengébbek közé, öt pedig a jók és kiválóak csoportjába. A Borda rangsor kizárólag sorrendet mutat, ezért abból az egyes gyárak egymáshoz viszonyított teljesítményére nem szabad következtetéseket levonni. sen kisebb, míg a QUALITY 5, ENERGY 3 és a LOSS 1 mutatókat lényegesen nagyobb súlyúnak ítélte, mint a súlyozás nélküli Borda módszer. A kiválasztott gyárak Borda (BORDA) és az AHP-súlyozott Borda (AHP BORDA) rangsorát, valamint a sorrend pontszámok összegét szintén a 3. táblázat mutatja. Ez utóbbit 0-1 közé skáláztuk a jobb összehasonlíthatóság érdekében. A BORDA és az AHP BORDA módszer által meghatározott rangsor csak kis mértékben tér el egymástól. A legnagyobb változás az $a 02$ és az a05 kódjelű gyár rangsorváltása, melynek oka, hogy azok a mutatók, melyekben az a02 gyár mutatott gyenge teljesítményt alulsúlyozásra, míg azok melyekben, a05 mutatott gyengét, felülsúlyozásra kerültek.

\section{A TOPSIS-módszer eredményei}

A harmadik, az AHP-súlyozott TOPSIS-módszer (AHP TOPSIS) rangsora lényegesen jobban eltér az előző két módszer eredményétől (3. táblázat). A legjobb és a legrosszabb gyárak rangsora lényegében nem változott, de a közöttük levő gyárak $(a 02, a 03, a 05)$ rangsora a Borda módszerhez viszonyítva egy, míg az AHP-súlyozott Borda módszerhez képest két helyen is változott. Érdemes megvizsgálni az AHP TOPSIS-módszer által adott teljesítményértékeket is a rangsorváltás értelmezéséhez. A

3. táblázat

A kiválasztott gyárak teljesítményrangsora és teljesítményértéke különböző módszerekkel értékelve

\begin{tabular}{|c|c|c|c|c|c|c|c|c|}
\hline \multicolumn{5}{|c|}{ Teljesítményrangsor } & \multicolumn{4}{|c|}{ Teljesítményérték } \\
\hline Gyár & BORDA & $\begin{array}{c}\text { AHP } \\
\text { BORDA }\end{array}$ & $\begin{array}{c}\text { AHP } \\
\text { TOPSIS }\end{array}$ & $\begin{array}{c}\text { AHP } \\
\text { UTILITY FN }\end{array}$ & BORDA & $\begin{array}{c}\text { AHP } \\
\text { BORDA }\end{array}$ & $\begin{array}{c}\text { AHP } \\
\text { TOPSIS }\end{array}$ & $\begin{array}{c}\text { AHP } \\
\text { UTILITY FN }\end{array}$ \\
\hline $\mathrm{a} 01$ & 73 & 73 & 73 & 72 & 0,893 & 0,971 & 0,509 & 0,414 \\
\hline $\mathrm{b} 01$ & 71 & 70 & 63 & 67 & 0,822 & 0,888 & 0,669 & 0,565 \\
\hline b02 & 20,5 & 20 & 24 & 11 & 0,352 & 0,393 & 0,844 & 0,870 \\
\hline $\mathrm{a} 03$ & 15 & 17 & 9 & 19 & 0,318 & 0,369 & 0,872 & 0,848 \\
\hline $\mathrm{a} 02$ & 10 & 5 & 11 & 20 & 0,262 & 0,216 & 0,869 & 0,846 \\
\hline $\mathrm{a} 05$ & 8 & 9 & 7 & 9 & 0,254 & 0,265 & 0,875 & 0,895 \\
\hline $\mathrm{a} 04$ & 1 & 1 & 2 & 1 & 0,111 & 0,114 & 0,921 & 0,919 \\
\hline
\end{tabular}

\section{A teljesítménymutatók fontosságának meghatározása AHP-módszerrel és az ezzel súlyozott Borda rangsor}

A Borda módszer minden teljesítménymutatót azonos fontosságúnak tekint, ezért elemzésünk második módszere ezt módosította a mutatók fontosságának figyelembevételével. A teljesítménymutató-hierarchia négy fö csoportjából a minőségkategória tartalmazza a legtöbb mutatót, mely 21 páros összehasonlítást eredményezett. A páros összehasonlítások mátrixának konzisztenciahányadosa 4,1\%, amely elfogadható eredmény. Az energiakategória esetében 3, míg a veszteségek és az OEE-kategória esetében csak 1-1 összehasonlításra volt szükség, ezeknél a konzisztenciahányados mind $0,0 \%$. Végül a fö csoportok értékelése során a 6 páros összehasonlítás, 2,6\%-os konzisztenciahányadost eredményezett, ami szintén elfogadható eredmény. A vállalat szakértői egyetértettek abban, hogy az AHP-súlyok valósan tükrözik a vállalat stratégiáját. A módszer a QUALITY 1, 4, 6, 7 mutatókat lényege-
11. helyre sorolt gyár (a02) összesített teljesítménye csak 6\%-kal marad el a rangsorban a 2 . helyen álló gyárétól (a04), míg a 11. és a 7. helyen álló gyárak $(a 02-a 05)$ között az eltérés kevesebb, mint 1\%. Ez jól szemlélteti, hogy az összteljesítmény-rangsorként való megjelenítése eltúlozhatja a gyárak közötti különbségeket, ami alááshatja a módszerbe vetett bizalmat és így akadályozhatja a gyárak közötti együttműködést.

\section{A hasznossági függvény alkalmazása}

A negyedik módszerrel, az AHP-súlyozott hasznossági függvények használatával egy olyan módszert kívántunk létrehozni, mely a teljesítményfejlesztés szempontjából a gyárak magatartását a vállalat stratégiájához igazítja. A hasznossági függvény egy meghatározott küszöbteljesítmény alatti nulla értéke a gyárakat ezen érték meghaladására ösztönzi, ezen érték alatti teljesítmény esetén a teljesítményversenyben jelentős hátrányban részesülnek. A kiváló szintű teljesítmény elérése után adott többlet- 
pontszám csökkentése, a már kiváló mutatók helyett a gyengébb mutatók javítására helyezi a hangsúlyt. A módszer által meghatározott sorrendet és összesített teljesítményértékeket a 3. táblázat AHP UTILITY FN oszlopa tartalmazza. Ennek az értékelésnek a rangsora két gyár esetében tér el jelentősen a Borda módszerétől. A b02 gyár rangsora a Borda módszerhez képest jelentösen javult, míg az a02 gyáré romlott. Ennek oka egyrészt az lehet, hogy a b02 gyár két olyan teljesítménymutatóban volt jobb az a02 gyárnál, melyet az AHP-módszer felülsúlyoz, másrészt az a02 gyár négy mutatóban is a kiváló kategória legmagasabb részén szerepel, melyet a hasznossági függvény csak kisebb részben jutalmaz. A hasznossági függvény összesített értékét elemezve megfigyelhetjük, hogy a két legrosszabb teljesítményű gyár összesített mutatója elmarad az AHP TOPSIS-módszer értékétől. Ennek oka az lehet, hogy b01 gyár öt mutatóban, míg az a01 négyben nem érte el a küszöbértéket.

A többi gyár esetében az AHP TOPSIS és az AHP UTILITY FN-módszer nagyon hasonló értéket ad. A négy módszer eredményeit megvizsgálva megválaszolhatjuk Q1 kutatási kérdésünket: a vállalatok összesített teljesítményéről az AHP TOPSIS-módszer értéke adja a leginkább valós képet. A hasznossági függvény valamennyire eltorzíthatja ezt a képet, annak speciális alakja miatt. A Borda módszeren alapuló rangsorok nem adnak információt a gyárak teljesítményének egymáshoz való arányáról, és a rangsor olyan veszélyt is hordoz, hogy a felületes szemlélö azt gondolhatja, a rangsorban az egyes gyárak teljesítménye között azonos a távolság, ami a legritkább esetben igaz. A Q2 kutatási kérdésre a válasz: a teljesítményfejlesztő programokat az AHP-súlyozott hasznossági függvényeken alapuló módszer támogathatja a legjobban, mivel a hasznossági függvény helyes megválasztásával befolyásolhatjuk, hogy a vállalatok milyen területek javítására helyezzék a hangsúlyt. A módszer eredményét rangsorként megjelenítve serkenthetjük a versenyt, amit az összesített teljesítményérték megjelenítésével árnyalhatunk, elősegítve a gyárak közötti hatékony együttmüködést és tudásmegosztást.

\section{A teljesítmény időbeli alakulásának elemzése}

A teljesítmény időbeli alakulásának elemzéséhez a négy módszer szerinti összegzést mind a három év adataira elvégeztük. Az eredményeket a kiválasztott gyárakra és a vállalat egészére (mint átlag) a 4. és 5. táblázat mutatja. A Borda és az AHP-súlyozott Borda rangsorok nem alkalmasak a teljesítmény nyomon követésére. A kiosztott rangsor helyeinek száma állandó, egy gyár csak a másik rovására javíthatja pozícióját. Ezt szemlélteti, hogy habár az a01 gyár 2014 és 2015 között teljesítményét az AHP TOPSIS-módszerrel mérve 25\%-kal javította, helyzete a Borda rangsorban mégsem változott. A $b 01$ gyár esetében a rangsor még rosszabb képet fest: hiába javította teljesítményét 2015 és 2016 között $8 \%$-kal, helyzete a Borda rangsorban mégis romlott. Az AHP-súlyozott TOPSIS és hasznossági függvényeken alapuló módszerek értékei ezzel szemben jól mutatják a teljesítmény változását. A javulás különösen a vállalat egészére vetített átlag esetében szembeötlő. Az AHP TOPSIS-módszerrel mérve az összes gyár teljesítményértékének átlaga több mint 7\%-kal javult 2014 és 2016 között. A Q3 kutatási kérdésre így a válasz: a gyárak teljesítményének időbeli nyomon követésére az AHP-súlyozott TOPSIS-módszer összesített teljesítményértéke lehet a legjobb módszer. Fontos, hogy a legjobb (ideal) - legrosszabb (anti-ideal) teljesítményhatárokat úgy válasszuk meg, hogy az lehetőséget biztosítson egy hosszabb időszak figyelemmel kísérésére, ezeket a határokat a gyárak ne tudják meghaladni a vizsgált időszak alatt. Alternatívaként használhatjuk az AHPsúlyozott hasznossági függvények módszerét is, de szem előtt kell tartanunk, hogy a hasznossági függvény milyen torzításokat okoz.

4. táblázat

A kiválasztott gyárak teljesítményrangsorának és összesített mutatójának változása 2014 és 2016 között

\begin{tabular}{llcccccccc}
\hline & & \multicolumn{3}{c}{ teljesítményrangsor } & & \multicolumn{3}{c}{ teljesítményérték } \\
gyár & módszer & 2014 & 2015 & 2016 & & 2014 & 2015 & 2016 \\
\hline a01 & Borda & 73 & 73 & 73 & AHP TOPSIS & 0,401 & 0,509 & 0,452 \\
& AHP Borda & 73 & 73 & 73 & AHP UTILITY FN & 0,360 & 0,414 & 0,395 \\
\hline b01 & Borda & 67 & 71 & 68 & AHP TOPSIS & 0,617 & 0,669 & 0,681 \\
& AHP Borda & 68 & 70 & 69 & AHP UTILITY FN & 0,512 & 0,565 & 0,624 \\
\hline b02 & Borda & 21 & 20,5 & 17 & AHP TOPSIS & 0,783 & 0,844 & 0,863 \\
& AHP Borda & 23 & 20 & 19 & AHP UTILITY FN & 0,838 & 0,870 & 0,895 \\
\hline a03 & Borda & 12 & 15 & 16 & AHP TOPSIS & 0,880 & 0,872 & 0,889 \\
& AHP Borda & 13 & 17 & 15 & AHP UTILITY FN & 0,869 & 0,848 & 0,867 \\
\hline a02 & Borda & 6 & 10 & 14 & AHP TOPSIS & 0,868 & 0,869 & 0,874 \\
& AHP Borda & 4 & 5 & 9 & AHP UTILITY FN & 0,834 & 0,846 & 0,857 \\
\hline a05 & Borda & 11 & 8 & 3 & AHP TOPSIS & 0,860 & 0,875 & 0,895 \\
& AHP Borda & 10 & 9 & 6 & AHP UTILITY FN & 0,880 & 0,895 & 0,909 \\
\hline \multirow{2}{*}{ a04 } & Borda & 1 & 1 & 1 & AHP TOPSIS & 0,932 & 0,921 & 0,911 \\
& AHP Borda & 1 & 1 & 1 & AHP UTILITY FN & 0,910 & 0,919 & 0,914 \\
\hline
\end{tabular}


5. táblázat

A 73 gyár átlagos összesített teljesítménypontszám alakulása különböző módszerekkel vizsgálva

\begin{tabular}{llll} 
módszer & 2014 & 2015 & 2016 \\
\hline AHP TOPSIS & 0,745 & 0,769 & 0,803 \\
AHP UTILITY FN & 0,695 & 0,742 & 0,782 \\
\hline
\end{tabular}

\section{Összefoglalás}

Cikkünk a vállalati teljesítményfejlesztő programok viszonylag csekély számú kvantitatív kutatásaihoz kívánt hozzájárulni a teljesítménymutatók többváltozós döntési modelleken alapuló módszereinek összehasonlításával. Kutatásunk célja annak vizsgálata volt, hogy milyen különbségek figyelhetők meg az egyes többszempontú döntési modelleken alapuló teljesítményösszegző módszerek között, és melyek lehetnek alkalmasak az összesített teljesítmény valós megjelenítésére. Esettanulmányunk megállapításainak korlátja, hogy bár viszonylag nagyszámú gyár adatain és tapasztalatán alapul, a gyárak egy vállalatcsoportba tartoznak. Érdemes lenne az elemzést más vállalatcsoportra is elvégezni, megállapításaink megerősítése céljából. Kutatási kérdéseinket megválaszolva megállapíthatjuk, hogy az alkalmazott többváltozós döntési modelleken alapuló teljesítményösszegző eljárások közül az AHPsúlyozott TOPSIS-módszer összesített teljesítményértéke adja a leginkább valós képet a vizsgált gyárak összesített teljesítményéről. Ez a módszer a legjobb és a legrosszabb teljesítményhatárok körültekintő megválasztásával képes a teljesítmény időbeli változását is nyomon követni, mely fontos információt hordoz a teljesítményfejlesztő programok sikerességének vizsgálatában. A Borda módszeren alapuló rangsorolások nem képesek a gyárak teljesítménykülönbségének mértékét megjeleníteni, sem a teljesítmény időbeli változását leírni. Az, hogy a módszer nem képes megjeleníteni a teljesítménykülönbség mértékét, a felületes szemlélő számára félrevezető információt sugározhat és ezen keresztül negatív hatással lehet a vállalati kooperációra és tudásmegosztásra. Végül a vizsgált módszerek közül felhívjuk a figyelmet a hasznossági függvényeken alapuló összegzési módszerekben rejlö lehetőségekre, melyek helyes megválasztásával befolyásolhatjuk a gyárak teljesítményfejlesztési magatartását.

A cikkben leírt teljesítményösszegzési és rangsorolási módszerek elsősorban olyan környezetben alkalmazhatók, ahol számos vállalat végez hasonló tevékenységet, teljesítménymutatóik összehasonlíthatók és adataikat egymás között meg tudják osztani. A teljesítmény ilyen módon történő összehasonlítása és az ahhoz kapcsolódó verseny jelentős mértékben elősegítheti a teljesítményfejlesztést. Az eredményes gyakorlati alkalmazást a megfelelöen megválasztott teljesítményösszegzési módszeren kívül számos más tényező befolyásolhatja. Ezekbe beletartozhat a teljesítménymutatók megválasztása, a versenyhez kapcsolódó motivációs rendszer, valamint a legjobb gyakorlatok azonosításának és megosztásának folyamatai. Cikkünkben ezekkel a kérdésekkel nem foglalkoztunk, azt további kutatások vizsgálhatják. A TOPSIS és a hasznossági függvényeken alapuló módszer egy vállalat esetében is alkalmazható az összesített teljesítmény időbeli nyomon követésére. Ebben az esetben a legjobb (ideal) - legrosszabb (anti-ideal) teljesítményhatárokat, vagy a hasznossági függvény minimum-maximum értékeit valamilyen elméleti korlát alapján célszerü megválasztani. A TOPSIS-módszer lehetőséget nyújthat több, a piacon egyedül versenyzö, de hasonló tevékenységet végző vállalat teljesítményének anonim összehasonlítására is, mely serkentőleg hathat azok versenyképességének javítására. A szereplők ilyen módon történő együttmüködése csökkentheti a számos gyárral rendelkező termelési hálózatok versenyelönyét. Az Európai Bizottság által létrehozott Business Innovation and Virtual Enterprise Environment keretében kutatott kulcsmutató rendszer (Diamantini et al., 2013) lehet példa egy ilyen együttműködésre, mely hasonló célokat tűzött ki és felvázolt egy lehetséges megvalósítási módot.

\section{Felhasznált irodalom}

Akyuz, A.G. - Erkan, T.E. (2010): Supply chain performance measurement: a literature review. International Journal of Production Research, 48(17), p. 5137-5155. https://doi.org/10.1080/00207540903089536

Bana e Costa, C.A. - Vansnick, J.-C. (1994): MACBETH - An interactive path towards the construction of cardinal value functions. International Transactions in Operational Research, 1(4), p. 489-500. https://doi. org/10.1016/0969-6016(94)90010-8

de Borda, J.-C. (1781): Mémoire sur les élections au scrutin, Histoire de l'Académie Royale des Sciences. Paris

Chan, F.T.S. (2003): Performance Measurement in a Supply Chain. The International Journal of Advanced Manufacturing Technology, 21(7), p. 534-548. https:// doi.org/10.1007/s001700300063

Colotla, I. - Shi, Y. - Gregory, M. J. (2003): Operation and performance of international manufacturing networks. International Journal of Operations \& Production Management, 23(10), p. 1184-1206. https://doi. org $/ 10.1108 / 01443570310496625$

Demeter K. - Losonci D. (2011): Lean termelés és üzleti teljesítmény - nemzetközi empirikus eredmények. Vezetéstudomány/Budapest Management Review, 42(10), p. 14-27.

Deming, W. E. (1994): The new economics: for industry, government, education. Cambridge, MA: MIT Press

Diamantini, C. - Potena, D. - Storti, E. (2013): A Logic-Based Formalization of KPIs for Virtual Enterprises. In: Franch, X. - Soffer, P. (eds.) (2013): Advanced Information Systems Engineering Workshops. CAiSE 2013. Lecture Notes in Business Information Processing, 148, Berlin, Heidelberg: Springer, p. 274-285. https://doi.org/10.1007/978-3-642-38490-5_26

Eisenhardt, K. M. (1989): Building Theories from Case Study Research. Academy of Management Review, 14(4), p. 532-550. https://doi.org/10.5465/ AMR.1989.4308385 
Ferdows, K. - Thurnheer, F. (2011): Building factory fitness. International Journal of Operations \& Production Management, 31(9), p. 916-934. https://doi. org/10.1108/01443571111165820

Fishburn, P. C. (1967): Methods of Estimating Additive Utilities. Management Science, 13(7), p. 435-453. https://doi.org/10.1287/mnsc.13.7.435

Gunasekaran, A. - Kobu, B. (2007): Performance measures and metrics in logistics and supply chain management: a review of recent literature (1995-2004) for research and applications. International Journal of Production Research, 45(12), p. 2819-2840. https://doi. org/10.1080/00207540600806513

He, H. - Baruch, Y. - Lin, C.-P. (2014): Modeling team knowledge sharing and team flexibility: The role of within-team competition. Human Relations, 67(8), p. 947-978. https://doi.org/10.1177/0018726713508797

Ho, W. $-X u, X$. - Dey, P. K. (2010): Multi-criteria decision making approaches for supplier evaluation and selection: A literature review. European Journal of Operational Research, 202(1), p. 16-24. https://doi.org/10.1016/j.ejor.2009.05.009

Hwang, C.-L. - Yoon, K. (1981): Methods for Multiple Attribute Decision Making, in: Multiple Attribute Decision Making: Methods and Applications A State-of-the-Art Survey. Berlin Heidelberg: Springer, p. 58-191. https://doi.org/10.1007/978-3-642-48318-9_3

Kása R. - Réthi G. (2017): Fuzzy logikán alapuló modellezési módszerek gazdálkodástudományi alkalmazásának episztemológiai megközelítése. Vezetéstudomány/ Budapest Management Review, 48(4), p. 84-99. https://doi.org/10.14267/VEZTUD.2017.04.10

Kocaoğlu, B. - Gülsün, B. - Tanyaş, M. (2013): A SCOR based approach for measuring a benchmarkable supply chain performance. Journal of Intelligent Manufacturing, 24(1), p. 113-132. https://doi.org/10.1007/s10845011-0547-z

Kovács G. (1999): A teljesítmény és menedzsmentje. Teljesítménymérés. In: Chikán A. - Demeter K. (eds.) (1999): Az értékteremtő folyamatok menedzsmentje. termelés, szolgáltatás, logisztika. Budapest: Aula, p. 531-567.

Kwiesielewicz, M. - van Uden, E. (2004): Inconsistent and contradictory judgements in pairwise comparison method in the AHP. Computers \& Operations Research, 31(5), p. 713-719. https://doi.org/10.1016/S03050548(03)00022-4

Lai, J. - Lui, S. S. - Tsang, E. W. K. (2016): Intrafirm Knowledge Transfer and Employee Innovative Behavior: The Role of Total and Balanced Knowledge Flows. Journal of Product Innovation Management, 33(1), p. 90-103. https://doi.org/10.1111/jpim.12262

London Stock Exchange (2015): A London Stock Exchange honlapja (On-line) Available at: http://www.londonstockexchange.com/exchange/news/market-news/ market-news-detail/SAB/12576961.html Hozzáférés dátuma: 2071.03.11.

Mefford, R. N. - Bruun, P. (1998): Transferring world class production to developing countries: A strategic mo- del. International Journal of Production Economics, 56-57, p. 433-450. https://doi.org/10.1016/S09255273(98)00085-1

Muchiri, P. - Pintelon, L. (2008): Performance measurement using overall equipment effectiveness (OEE): literature review and practical application discussion. International Journal of Production Research, 46(13), p. 3517-3535. https://doi.org/10.1080/00207540601142645

Neely, A. - Gregory, M. - Platts, K. (1995): Performance measurement system design: A literature review and research agenda. International Journal of Operations \& Production Management, 15(4), p. 80-116. https:// doi.org/10.1108/01443579510083622

Netland, T. H. - Aspelund, A. (2013): Company-specific production systems and competitive advantage. International Journal of Operations \& Production Management, 33(11), p. 1511-1531. https://doi.org/10.1108/ IJOPM-07-2010-0171

Netland, T. H. - Aspelund, A. (2014): Multi-plant improvement programmes: a literature review and research agenda. International Journal of Operations \& Production Management, 34(3), p. 390-418. https://doi. org/10.1108/IJOPM-02-2012-0087

Pennings, J. M. E. - Smidts, A. (2003): The Shape of Utility Functions and Organizational Behavior. Management Science, 49(9), p. 1251-1263. https://doi.org/10.1287/ mnsc.49.9.1251.16566

Pfeffer, J. - Sutton, R. I. (1999): The Knowing-Doing Gap: How Smart Companies Turn Knowledge into Action. Boston, MA: Harvard Business Review Press

Pomerol, J.-C. - Barba-Romero, S. (2000): Multicriterion Decision in Management: principles and practice. New York: Springer US. https://doi.org/10.1007/978-1-46154459-3

Rangone, A. (1996): An analytical hierarchy process framework for comparing the overall performance of manufacturing departments. International Journal of Operations \& Production Management, 16(8), p. 104119. https://doi.org/10.1108/01443579610125804

Saaty, T. L. (2004): Fundamentals of the analytic network process - Dependence and feedback in decision-making with a single network. Journal of Systems Science and Systems Engineering, 13(2), p. 129-157. https:// doi.org/10.1007/s11518-006-0158-y

Saaty, T. L. (1986): Decision Making for Leaders: The Analytic Hierarchy Process for Decisions in a Complex World. Pittsburgh, PA: RWS Publications

Saaty, T. L. (1977): A scaling method for priorities in hierarchical structures. Journal of Mathematical Psychology, 15(3), p. 234-281. https://doi.org/10.1016/00222496(77)90033-5

Schroeder, R. G. - Linderman, K. - Liedtke, C. - Choo, A. S. (2008): Six Sigma: Definition and underlying theory. Journal of Operations Management, 26(4), p. 536-554. https://doi.org/10.1016/j.jom.2007.06.007

Shi, Y. - Gregory, M. (1998): International manufacturing networks - to develop global competitive capabilities. Journal of Operations Management, 16(2-3), p. 195214. https://doi.org/10.1016/S0272-6963(97)00038-7 
Singh, R. K. (2013): Prioritizing the factors for coordinated supply chain using analytic hierarchy process (AHP). Measuring Business Excellence, 17(1), p. 80-97. https://doi.org/10.1108/13683041311311383

Stephens, S. (2001): Supply Chain Operations Reference Model Version 5.0: A New Tool to Improve Supply Chain Efficiency and Achieve Best Practice. Information Systems Frontiers, 3(4), p. 471-476. https://doi.org/10.1023/A:1012881006783

Supply Chain Council (2012): Supply Chain Operations Reference Model Revision 11.0.

Swink, M. - Jacobs, B. W. (2012): Six Sigma adoption: Operating performance impacts and contextual drivers of success. Journal of Operations Management, 30(6), p. 437-453. https://doi.org/10.1016/j.jom.2012.05.001

Tangen, S. (2005): Improving the performance of a performance measure. Measuring Business Excellence, 9(2), p. 4-11. https://doi.org/10.1108/13683040510602830

Ungan, M. (2005): Management support for the adoption of manufacturing best practices: key factors. International Journal of Production Research, 43(18), p. 3803-
3820. https://doi.org/10.1080/00207540500140989

de Waal, A. A. (2004): Stimulating performance-driven behaviour to obtain better results. International Journal of Productivity and Performance Management, 53(4), p. 301-316. https://doi.org/10.1108/17410400410533890

Wimmer Á. (2014): Teljesítménymenedzsment. In: Demeter K. (eds.) (2014): Termelés, szolgáltatás, logisztika. Az értékteremtés folyamatai. Budapest: Wolters Kluwer Kft., p. 331-361.

Wimmer Á. (2004): Üzleti teljesítménymérés az értékteremtés szolgálatában. Vezetéstudomány/Budapest Management Review, 35(9), p. 2-11.

Yazdi, M. M. (2013): Package "topsis.” Available at: https:// cran.r-project.org/package=topsis Hozzáférés dátuma: 2071.03.11.

Yin, R. K. (2003): Case studies research: Design and Methods. Thousand Oaks, CA.: SAGE Publications, Inc.

Zoltayné P. Z. - Wimmer Á. - Szántó R. (2007): Vezetői döntéshozatal és versenyképesség (The managerial decision making and the competitiveness). Vezetéstudomány/Budapest Management Review, 38(5), p. 18-28. 